\title{
ЗНАЧЕННЯ НЕЙРОФІЗІОЛОГІЧНОГО ФАКТОРА ВОКАЛЬНОГО ПРОЦЕСУ В СИСТЕМІ ПІДГОТОВКИ МАЙБУТНЬОГО АКТОРА
}

\author{
Гринь Л. О. \\ кандидат педагогічних наук, \\ доиент кафедри акторської майстерності та дизайну \\ Запорізький національний університет \\ вул. Жуковського, 66, Запоріжжя, Украӥна \\ orcid.org/0000-0002-8580-044X \\ l-grin@ukr.net
}

Шупранова Д. О.

магістр

Запорізький національний університет

вул. Жуковського, 66, Запоріжжя, Украӥна

orcid.org/0000-0002-3214-8531

shupranovadarina@gmail.com

Ключові слова:
професійна підготовка
акторів, пеорія
голосоутворення, будова
голосового апарату, вокально-
технічний комплекс
Проблема удосконалення якості професійного навчання майбутнього актора музично-драматичного театру, яка характеризується орієнтацією на підвищення рівня його вокальної майстерності, стає актуальною в полі зору дослідників. Чим ефективнішою буде вокальна підготовка студента, тим якіснішою виявиться його вокальна діяльність. У статті розглянуто науково-теоретичні аспекти багатьма видатними зарубіжними вченими та визначено практичні підходи до означеної проблеми. Традиції вокальної педагогіки спираються на методи формування виконавського рівня співочого мистецтва, відшліфованих багатовіковими надбаннями в історико-культурному розвитку національних рис цього народу i утверджених через стилістичні епохи й напрями. Вокальний голос актора - це передусім «професійний інструмент», який має складний механізм, що у процесі подальшого розвитку зазнає різних зовнішніх впливів. Проте цей професійний «інструмент» потребує застосування різноманітних спеціальних методичних прийомів для подолання психологофізіологічних чинників, що перешкоджають професійному становленню виконавця - актора-вокаліста. Анатомічна будова голосового апарату дуже складна, але необхідна для розуміння актором процесу формування вокальних звуків. Розглядаючи спів як одну з функцій організму людини, зазначимо, що він підпорядковується основним закономірностям діяльності нервової системи, яка керує життєдіяльністю всього організму. Сучасні знання 3 нейрофізіології дають можливість зрозуміти схему функціонування голосового комплексу й керувати його правильним розвитком не тільки на підставі суб'єктивних уявлень та інтуїції викладача, а й на основі наукових розробок. Специфіка педагогічного спрямування вокального навчання у вищих навчальних закладах вимагає володіння науково-теоретичною базою знань 3 вокальної педагогіки, усвідомлення закономірностей процесу голосоутворення та високого рівня вокально-технічного комплексу вмінь та навичок. 


\title{
THE IMPORTANCE OF THE NEUROPHYSIOLOGICAL FACTOR OF VOCAL PROCESS IN THE TRAINING SYSTEM OF A FUTURE ACTOR
}

\author{
Grin' L. O. \\ Candidate of Pedagogical Sciences, \\ Associate Professor at the Department Author's Skills and Desing \\ Zaporizhzhia National University \\ Zhukovsky str., 66, Zaporizhzhia, Ukraine \\ orcid.org/0000-0002-8580-044X \\ l-grin@ukr.net
}

Shupranova D. O.

Master

Zaporizhzhia National University

Zhukovsky str., 66, Zaporizhzhia, Ukraine

orcid.org/0000-0002-3214-8531

shupranovadarina@gmail.com

Key words:

professional training of actors, theory of the process of voice formation, structure of the apparatus, of vocal and technical complex.
The problem of improving the quality of professional training of a future actor of Music and Drama Theater, which is characterized by an orientation to increase the level of their vocal skills becomes relevant in the field of view of researchers. The more effective the vocal training of the student, the better their vocal activity will be. The article considered scientific and theoretical aspects of many outstanding foreign scientists and defined practical approaches to this problem. The traditions of vocal pedagogy are based on the methods of formation of the performing level of singing art, polished by centuries-old achievements in the historical and cultural development of the national features of this people and approved through stylistic epochs and directions. The vocal voice of the actor is primarily a "professional instrument", which has a complex mechanism, in the process of further development undergoes various external influences. However, this professional "instrument" requires the use of various special methodological techniques to overcome psycho-physiological factors that prevent the professional formation of the performer - actor-vocalist. The anatomical structure of the voice apparatus is very complex, but necessary for the actor to understand the process of formation of vocal sounds. Considering singing as one of the functions of the human body, it is subject to the main patterns of activity of the nervous system, which controls the life of the whole body. Modern knowledge of neurophysiology makes it possible to understand the functioning of the voice complex and to manage its correct development not only on the basis of subjective perceptions and intuition of the teacher, but also on the basis of scientific developments. The specificity of the pedagogic direction of vocal education in higher education institutions requires the possession of a scientific and theoretical knowledge base on vocal pedagogy, awareness of the patterns of the process of voice formation and a high level of vocal and technical complex of skills.
Постановка проблеми. На сучасному етапі розвитку театрального мистецтва велику роль у драматичних постановках відіграє вокальна підготовка актора. Сьогодні надзвичайно гостро постає проблема підготовки драматичного актора універсального типу - актора, який повинен не тільки проявляти акторські здібності під час дії, а й розкривати свою індивідуальність у процесі створення вокально-сценічного образу під час вистави. Чим ефективнішою буде вокальна підготовка студента, тим якіснішою виявиться його діяльність, тому що підготовка студента та його 
майбутня професійна діяльність $€$ взаємозумовленими

Специфіка діяльності актора музично-драматичного театру являє собою своєрідний «синтез видів мистецтв»- мистецтва мовлення, акторської гри, співу, сценічної дії та хореографії. Вокальне мистецтво $\epsilon$ провідним в оволодінні різновидами діяльності майбутнього актора музично-драматичного театру. Відтак вокальна підготовка $є$ важливим компонентом фахової підготовки студентів напряму «театральне мистецтво» у вищій школі, a формування вокальної майстерності актора потребує вдосконалення змісту вокальної підготовки майбутнього фахівця.

Аналіз фундаментальних праць 3 теорії вокального мистецтва свідчить про те, що такі вчені, як Л. Дмитрієв, Ф. Засєдатєлєв, В. Морозов, О. Стахевич насамперед приділяли увагу таким аспектам, як техніка постановки голосу та фізіологія цього процесу; І. Павлов, Л. Работнов, І. Сеченов та інші досліджували вчення про вищу нервову діяльність і фізіологічну роль органів почуття під час співу. Вплив акустичних особливостей на процес голосоутворення визначали у своїх теоріях Л. Работнов, Р. Юссон та інші; дослідження Л. Виготського, О. Єлісєєва, А. Здановича, Р. Нємова, Н. Рождєствєнської, Б. Теплова та інших стали психологічною базою у розробці теоретичних та методичних аспектів процесу формування вокальної майстерності майбутніх акторів.

Постановка завдання. Однак проблеми підготовки акторів музично-драматичного театру засобами вокального мистецтва, зокрема щодо формування вокальної майстерності, недостатньо розкриваються в науково-педагогічних розробках. Специфіка педагогічного спрямування вокального навчання у вищих навчальних закладах вимагає високого рівня вокально-технічного комплексу вмінь та навичок, усвідомлення закономірностей процесу голосоутворення, володіння науково-теоретичною базою знань 3 проблеми використання вокального мистецтва у професійній підготовці актора музично-драматичного театру. Тому метою нашої статті $\epsilon$ визначення усвідомлення та ролі процесу нейрофізіологічного фактору під час формування вокального голосу майбутнього актора.

Виклад основного матеріалу дослідження. Традиції вокальної педагогіки спираються на методи формування виконавського рівня співочого мистецтва, відшліфовані багатовіковими надбаннями в історико-культурному розвитку національних рис народу і утверджені через стилістичні епохи й напрями. Вокальне мистецтво за своєю природою синтетичне і складається 3 нерозривної єдності декількох елементів: музики, співу та слова. Вокальний голос - це домінуючий складник в системі вокального мистецтва. Розвиток вокального голосу грунтується на методичних засадах вітчизняної та зарубіжної вокальної педагогіки, глибокому вивченні вокальних та музичних традицій кожного народу.

Вокальний голос актора - це перш за все «професійний інструмент», який має складний механізм. Проте цей професійний «інструмент» у процесі подальшого розвитку зазнає різних зовнішніх впливів (об'єктивних і суб'єктивних) у різні вікові періоди дозрівання організму й, відповідно, потребує застосування різноманітних спеціальних методичних прийомів для подолання психолого-фізіологічних чинників, що перешкоджають професійному становленню виконавця актора-вокаліста.

Сучасні знання з нейрофізіології дають можливість зрозуміти схему функціонування голосового комплексу, процес керування його правильним розвитком, що будується не тільки на підставі суб'єктивних уявлень та інтуїції викладача, а й на основі наукових розробок. Співочий голос керується й регулюється рефлекторно. Часто ті технічні прийоми, які рекомендує виконувати викладач (поради 3 дихання, керування звуком тощо), студент не може повторити відразу через певні фізіологічні можливості його голосового апарату. Саме тому врахування нейрофізіологічного фактора вокального процесу та фізіологічних особливостей розвитку студента є обов'язковою вимогою на шляху успішного розвитку голосового апарату та художньо-виконавських якостей співака-актора.

Розкриємо сутність процесу врахування нейрофізіологічного фактора вокального процесу, який забезпечується трьома передумовами: розумінням студентами нейрофізіологічного процесу співу, свідомим ставленням до роботи на заняттях, активним формуванням пізнавальної активності. Правилами реалізації цього процесу є:

- забезпечення розуміння студентами потреби в теоретичних знаннях про нейрофізіологічний процес співу;

- формування пізнавальних мотивів до оволодіння актором вокальною майстерністю та активного їх використовування в навчально-виховному процесі шляхом вивчення нейрофізіологічного фактора вокального процесу;

- залучення кожної особистості до активної пізнавальної діяльності з питань нейрофізіологічного фактора вокального процесу, всіляко заохочуючи щонайменші успіхи;

- створення умов для повсякденного застосування теоретичних знань 3 нейрофізіології процесу співу під час власної вокальної практики;

- урахування індивідуальних фізіологічних можливостей майбутнього актора у процесі розвитку вокального голосу. 
Аналізуючи останні досягнення 3 фізіології, психології, фоніатрії, наголошуємо на тому, що спів $є$ не тільки функцією гортані, а й складною інтегрованою функцією всього організму, у якій велике значення мають функції вищої центральної нервової системи. Академік Л. Орбелі зазначав, що голосовий апарат - це «ідеальний» музичний інструмент, здатний створювати художні образи. Саме досконалість роботи і функціонування мозку забезпечує голосовому апарату якості ідеального музичного інструмента, рівного якому наука ще не створила. У процесі формування вокального голосу викладач повинен наголошувати на тому, а студент розуміти, що завдяки складним біохімічним процесам мозку й периферійної нервової системи ноти, ритм, штрихи як схематичні умовні представлення перетворюються співаком на реальне звучання голосу, на реальну музичну мову, художній образ [1].

Видатні науковці В. Морозов, Р. Юссон, розробляючи питання утворення вокального звука, стверджували, що особливістю солоспіву є діяльність нервової системи співака, яка піддається не тільки музично-виконавському навантаженню, а й потребує постійного «налаштування» голосового апарату (музичного інструмента виконавця) [7; 9]. Відповідно до цього викладач повинен постійно враховувати інтелектуальний потенціал студента, його фізіологічну розвиненість, допомагати підвищувати його співочий тонус, використовуючи для цього позитивний емоційний вплив, роблячи тим самим заняття доступними та зрозумілими. Водночас слід уникати всіх негативних подразників, які призводять до підвищеної втомлюваності, погіршення загального настрою студента.

Діяльність центральної нервової системи $є$ вищою формою фізіологічних процесів. Процес мислення, за словами I. Сєченова, супроводжується рефлекторним мускульним зусиллям [8]. 3 огляду на це ми можемо зробити висновок, що втома виникає спочатку у відповідних клітинах головного мозку, а не в м'язах. Це твердження пояснює ряд незрозумілих раніше явищ - погіршення звучання і навіть втрату голосу під час негативних емоцій, стресів тощо.

Визначаючи ці теоретичні аспекти, доходимо висновку, що розвиток співочого голосу безпосередньо залежить від знань з фізіології голосового апарату: усвідомлення вокалістом сутності процесу звукоутворення, закономірностей резонування, специфіки вокального мовлення, артикуляції, дихальних рухів, їх ролі у процесі фонації.

На думку науковця Л. Дмітрієва, «техніку співу потрібно розглядати як результат утворення численних зв'язків у мовноруховому аналізаторі, зв'язків, які виникають для здійснення певного виконавського завдання» [4]. Звук народжується в гортані на голосових зв'язках як результат їхньої взаємодії з видихуваним повітрям 3 легень. Однак цей звук ще не є достатньо сформованим. Видихуване повітря надходить до гортані знизу 3 легень, проходячи через бронхи та трахеї. Формування мовленнєвої фонації відбувається за допомогою артикуляційних органів: глотки, м'якого та твердого піднебіння, язика та губ. Співочий звук під час фонації формується в розташованих над гортанню порожнинах, таких як глотка, носоглотка, порожнина рота. Під час видиху з ротового отвору звук голосу вже має закінчене забарвлення, формуючись у той чи інший голосний або приголосний [4].

Звичайний звук людського голосу $є$ результатом руху м'язів і зчленувань голосового апарату. Під час співу ці рухи надзвичайно різноманітні: ними визначається сила, висота, темброві барви голосу, тривалість звуку, його динаміка й подача слова. Головним завданням вокальної підготовки актора є усвідомлення «дисциплінованого» руху м'язової системи голосового апарату, тобто розуміння відчуття процесу формування голосу під час співу.

Оскільки «дисциплінований» рух м'язової системи голосового апарату зі своїми фізіологічними механізмами $є$ умовним рефлексом, то можна стверджувати, що загальні закони умовних рефлексів можуть бути застосовані й до вокально-технічних навичок. Постановка голосу актора (на заняттях з вокалу) - це процес встановлення правильного взаємозв'язку окремих частин голосового апарату. Процес співу здійснюється за допомогою системи периферичних механізмів, а саме: органів слуху та всього звукоутворювального рухомого апарату - легень, гортані глотки, язика, губ. Уся їх робота регулюється центральною нервовою системою та перебуває в тісному взаємозв'язку.

Анатомічна будова голосового апарату дуже складна, але необхідна для розуміння актором процесу формування вокальних звуків. М'язи голосового апарату під час фонації знаходяться в певному взаємовідношенні. Цей процес має назву «координація голосу». Координація, тобто злагоджена робота м'язів голосового апарату та музичного слуху, спрямована виконавцем на виконання технічних завдань (правильної інтонації співу), не завжди може бути більш чи менш досконалою. Тому координацію голосу слід вважати якісною характеристикою вокального звукоутворення.

Координація у співі пов'язується з м'язовими рухами в ділянці гортані, ротовою порожниною, органами слуху та диханням. Але самі по собі м'язи рухатись не можуть. Розглядаючи спів як одну з функцій організму людини, зазначимо, що 
він підпорядковується основним закономірностям діяльності нервової системи, яка керує життєдіяльністю всього організму.

Ф. Засєдатєлєв зазначав, що «спів - це не лише функція гортані, а й складна інтегрована функція всього організму, в якій велику роль відіграють вищі функції центральної нервової системи» [6]. Механізм роботи мозку, що керує процесом співу, $\epsilon$ механізмом утворення умовно-рефлекторних зв'язків та діяльності аналізаторів. Даючи характеристику процесу фонації, французький вчений Р. Юссон наголошував, що «фонація виникає як результат складних нервових та рухових процесів: руху м'язів гортані, установок рото-глоткових порожнин, особливих дихальних рухів» [9].

У процесі навчання співу й у подальшій професійній діяльності актор-вокаліст за допомогою органів слуху повинен навчитися розрізняти всі тонкощі звучання свого голосу, розвивати слухові уявлення про нього, свідомо контролювати діяльність голосового апарату, а в умовах самостійної підготовки використовувати ці навички самоконтролю для відпрацювання необхідних якостей вокального голосу. Так, дослідник О. Зданович зазначав, що процес звукоутворення вокального голосу залежить як від роботи центральної нервової системи, так і від слухових уявлень, що виникають у процесі співу [6, с. 55]. Вчений Л. Дмітрієв наголошував, що «саме звукові образи мають диктувати виконавські прийоми, технічні засоби для їх звукового втілення, тоді вся техніка буде побудована як вираження певних музично-виконавських завдань» [4, с. 234].

Висновки. Таким чином, конкретизуючи розуміння нейрофізіологічного процесу розвитку вокального голосу, ми визначили, що основним завданням його формування як «професійного інструмента» актора $\epsilon$ дисциплінування рухів м'язової системи голосового апарату, тобто набуття рухових навичок, що безпосередньо залежить від усвідомлення основних закономірностей звукоутворення, резонування, дихальних рухів, їх ролі у процесі фонації, знання фізіології голосового апарату, розвитку навичок координування роботи голосового апарату за допомогою вокально-слухового контролю. Дотримуючись у своїй науково-педагогічній роботі певних методів викладання вокальної підготовки майбутніх акторів музично-драматичного театру, викладач сприяє правильному розвитку вокального голосу студента, запобігає швидкій втомлюваності його голосового апарату, зберігаючи його на довгі роки. Кожен студент має різні потенційні й фізіологічні можливості, але, відповідально ставлячись до завдань викладача, прислухаючись до його зауважень, він може вдосконалювати свої вокальні дані. Урахування розглянутого процесу в системі вокальної підготовки майбутніх акторів вишу забезпечує ефективність якісного професійного навчання.

\section{Література}

1. Гнидь Б.П. Історія вокального мистецтва: підручник. Київ : НМАУ, 1994. 320 с.

2. Гринь Л.О. Теоретико-методичні основи вокальної підготовки майбутніх акторів : науково-методичний посібник для студентів спеціальності “Театральне мистецтво”. Запоріжжя : ЗНУ, 2011. 140 с., ноти.

3. Дмитриев Л.Б. Основы вокальной методики : учеб. пособ. Москва : Музыка, 1968. 676 с.

4. Жишкович М. Основи вокально-педагогічних навиків: Методичні поради для студентів вокальних факультетів вищих навчальних закладів культури і мистецтв III-IV рівнів акредитації. Львів, 2007. 43 с.

5. Зданович А.П. Некоторые вопросы вокальной методики. Москва : Музыка, 1965. 148 с.

6. Морозов В.П. Искусство резонансного пения. Основы резонансной теории и техники. Москва: Московская государственная консерватория им. П.И. Чайковского; Институт психологии РАН; Центр “Искусство и наука", 2002. 496 с. с илл.

7. Сеченов И.М. Избранные произведения. Москва: Учпедгиз, 1953. 368 с.

8. Юцевич Ю. Теорія і методика формування та розвитку співацького голосу: навч.-метод. посібник для викладачів та студентів мистецьких навчальних закладів, учителів шкіл різного типу. Київ: I3MH, 1998. 160 c. URL: http://kmvd.pnu.edu.ua

\section{References}

1. Gnyd B.P. (1994) Istoriya vokalnoho mystetstva: pidruchnyk [History of vocal art : textbook]. Kyiv: NMAU, . 320p.

2. Grin L.O. (2011) Teoretyko-metodychni osnovy vokalnoyi pidhotovky maybutnikh aktoriv: naukovo-metodychnyy posibnyk dlya studentiv spetsialnosti "Teatralne mystetstvo"[Theoretical and methodical bases of vocal preparation of future actors: scientifically methodical manual for the students of speciality the "Dramatic art"]. Zaporizhzhya : ZNU. 140 p.

3. Dmitriyev L.B. (1968) Osnovy vokalnoy metodiki: ucheb. Posob [Bases of vocal methodology: training manual]. Moscow: Muzyka. 676 p. 
4. Zhyshkovych M. (2007) Osnovy vokalno-pedahohichnykh navykiv: Metodychni porady dlya studentiv vokalnykh fakultetiv vyshchykh navchalnykh zakladiv kultury i mystetstv III-IV rivniv akredytatsiyi [Bases of vocally-pedagogical skills: Methodical advices for the students of vocal faculties ofhigher educational establishments of culture and arts of III-IV levels of accreditation]. Lviv. 43 p.

5. Zdanovich A.P. (1965) Nekotoryye voprosy vokalnoy metodiki [Some questions of vocal methodology]. Moscow: Muzyka. 148 p.

6. Morozov V.P. Iskusstvo rezonansnogo peniya. Osnovy rezonansnoy teorii i tekhniki [Art of the resonant singing. Bases of resonant theory and technique.]. Moskva: Moskovskaya gosudarstvennaya konservatoriya im. P.I. Chaykovskogo; Institut psikhologii RAN; Tsentr "Iskusstvo i nauka", 2002. 496 p.

7. Sechenov I.M. (1953) Izbrannyye proizvedeniya [Select works.]. Moscow : Uchpedgiz. 368 p.

8. Yutsevych YU. (1998) Teoriya i metodyka formuvannya ta rozvytku spivatskoho holosu: navch.-metod. posibnyk dlya vykladachiv studentiv mystetskykh navchalnykh zakladiv, uchyteliv shkil riznoho typu [Theory and methodology of forming and development of singer's voices: training methodical manual for the teachers and students of art educational establishments, teachers of art schools]. Kyiv: IZMN. 160 p. 